\title{
The re-co-construction of legitimacy of/through the Doing Business indicators
}

\author{
Amanda Perry-Kessaris"
}

\begin{abstract}
The present paper argues that the Doing Business indicators, their legitimacy (their ability to be defended through some logic or justification arising from standards) and the wider notions of legitimacy (the standards) that they promulgate are all best understood as social or, better still, 'econosociolegal constructions. It tracks their, primarily post-financial crisis, re-co-construction within and beyond the World Bank from servant of the private sector and discipliner of states to something approaching social champion. But it warns that the perceptions of legitimacy that have been generated by those indicators may well linger.
\end{abstract}

\section{Introduction}

This paper starts from the interrelated premises that (I) legitimacy and standards are mutually constitutive, (2) legitimacy and standards are co-constructed through social actions, interactions and regimes, in the context of prevailing rationalities, and (3) co-constructions are necessarily provisional and contingent, and therefore subject to re-co-construction, in particular as rationalities shift. It explores the validity and implications of these premises through one set of standards, the Doing Business indicators, which have been produced and distributed by the World Bank since 2004 to measure the roles played by state legal systems in business life around world, with special reference to the implications for economic development.

Legitimacy, as commonly defined, is constructed with reference to rules/standards - specifically (I) compliance with rules/standards or (2) the ability to be defended through some logic or justification arising from rules/standards. ${ }^{\mathrm{I}}$

Socio-legal specialists are particularly well versed in exposing the socially constructed and, therefore, contingent and provisional nature of all standards, of their implementation and of their legitimacy. Sociologically informed approaches seek to 'consistently and permanently address[es] the need to reinterpret law systematically and empirically as a social phenomenon' (Cotterrell, I998, p. I83). So we users of such approaches are ever attuned to the facts that, inside every standard, there lurks a debate, and that any standard can be abused or avoided. So well do we know these facts about the social life of standards that we risk taking them for granted, forgetting their origin, becoming blasé as to their enduring significance.

Indeed, it is instructive to remember that there remain all manner of standards by which sociolegal specialists remain blindly persuaded, of whose social life we remain entirely ignorant. For

* Professor of Law, Kent Law School. E-mail: a.perry-kessaris@kent.ac.uk, @aperrykessaris and https:// econosociolegal.wordpress.com. Sincere thanks to the editors and an anonymous reviewer for their comments.

I Legitimacy includes 'conformity to rule or principle, or to sound reasoning'. To be legitimate is to be 'conformable to law or rule; lawful, proper .... Normal, regular; conformable with a standard type', The Shorter Oxford English Dictionary on Historical Principles, vol. I. Oxford: Clarendon Press, I977. For other variations of the notion of legitimacy, including those with more specific technical application, see also Siems and Nelken (2017). 
example, a recent object-based enquiry caused me to notice the quietly forceful rule/standard commonly engraved on, materially embedded in, metallic measuring devices (in this case, a calliper): 'STANDARD at $20^{\circ}$.' Further investigation revealed that this international standard reference temperature for dimensional measurements was established after fierce debate at a time when the temperature scale was itself 'under serious study' (Dorion, 2007, pp. 2-3; see also PerryKessaris, 20I6a). The setting of this as the standard had a radical, on-going effect on the physical sciences that rarely to never cross most minds (Figure I). Furthermore, as the bent calliper pin pictured in Figure I reminds us, even agreed physical standards are always subject to abuse and avoidance.

All of this is to say that, repetitive though they may sometimes feel, exposés of the social life of rules/standards, in particular of the intertwined stories of their legitimacy and re-co-construction, remain a crucial socio-legal enterprise.

The present paper argues that the Doing Business indicators, their legitimacy (their ability to be defended through some logic or justification arising from standards) and the wider notions of legitimacy (the standards) that they promulgate are all best understood as social or, better still, 'econosociolegal' constructions. I use this ungainly term to highlight the facts that 'the economy and the law are mutually constitutive, and that both are in turn mutually constitutive of wider social life, including that part of social life relating to how we think and communicate about' the economic and the legal (Perry-Kessaris, 2015; 20I4).

This entanglement is especially significant given that the Doing Business indicators are produced and consumed in a development assistance context that sees people 'over here' defining how people 'over there' ought to think and communicate about the economic and the legal. Because indicators are socially constructed, they are contingent and provisional, and therefore stand to be reevaluated and reconstructed. But, as a technology of governance, they are subject to narrow control and vested interests.

This paper shows the legitimacy of the Doing Business indicators and the legitimacy that they seek to confer on state legal systems have been intensely contested, resulting in their on-going re-co-construction.

\section{Construction}

An indicator is a named collection of rank-ordered data that purports to represent the past or projected performance of some aspect of social (including economic and legal) life. It is useful to visualise the construction of indicators, and their legitimacy, as occurring in four stages, each of which is visualised in Figure 2: scanning, isolation, conversion and communication. At every stage of the process, actions and interactions are influenced by the dominant rationalities and resulting regimes.

When we construct an indicator, we scan social life to identify traces of the actions and interactions that appear, in the context of our specific rationality, to be important. Any of a wide range of rationalities or 'ways of apprehending the world' (Dryzek, 2005, p. 2) might inform our understanding of what is 'important'. The 'important' traces are then isolated and grouped according to what they are seen to represent. So, for example, the Doing Business focuses primarily on traces (records of time, cost, number of steps) relating to specific (inter)actions of/ between commercial actors and judges or bureaucrats. Next, the grouped traces are converted, through economic, mathematical and governance regimes, into named indicators. Finally, the indicator is ready to be communicated within the inward- and outward-facing regimes or systems of the producer and then beyond as it is distributed to and consumed by others. For example, the Doing Business indicators are produced and consumed by the World Bank, which then also distributes them for consumption by states, commentators and commercial actors. 

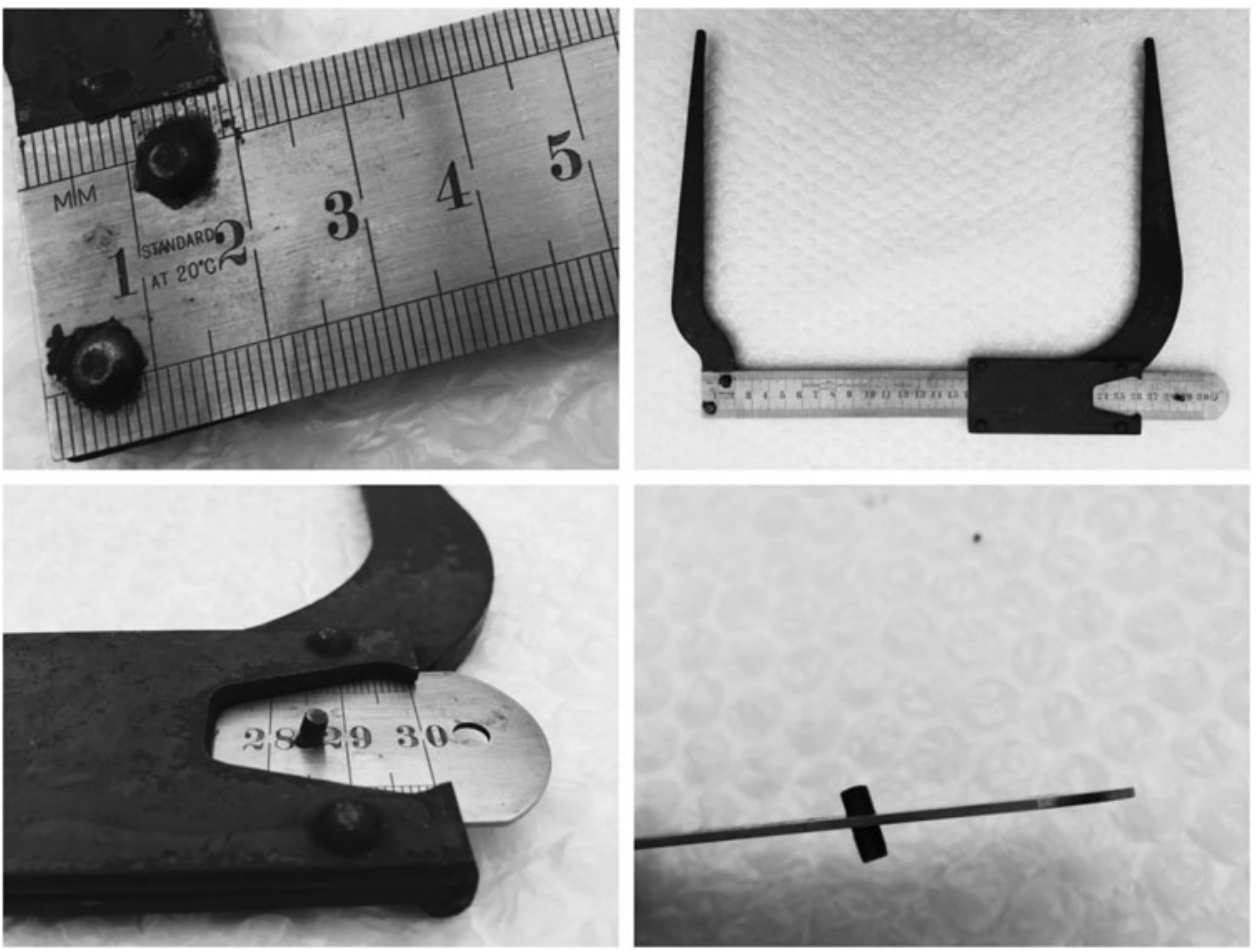

Figure I

The contingency of standards

Source: Preparatory studies for Perry-Kessaris (2016b).

\subsection{Legitimacy through indicators}

Once in circulation, indicators offer a standard against which to measure legal systems. For example, the Doing Business indicators are aggregated into an 'ease of doing business index', which ranks states and regions within them, thereby constructing the states' international reputation and, thereby, the terms on which it accesses technical and financial development assistance, which in turn triggers annual ministerial handwringing across the globe. ${ }^{2}$

2 Jason Yackee (2016) has criticised socio-legal commentators, and me specifically, for making over-blown, under-evidenced and 'provocative' claims as to the influence that the Doing Business indicators may have on the disbursement of aid (pp. I78, I79, I80, I82). In fact, my research in this field has primarily focused not (as Jackee suggests) on the direct impact of DB indicators on aid volume, but rather on the more diffuse and potentially pernicious roles played by indicators in stimulating and rewarding competition between states and regions to rise in Doing Business rankings (Perry-Kessaris, 2008b; 20I Ia; 20IIb) and of spreading what I have termed the 'investment climate discourse' (Perry-Kessaris, 2008a; 2008b), of which indicators form a part, in World Bank and client-state policy-making, as well as on the lack of evidence in support of the World Bank's contention that investors are at all motivated by Doing Business rankings (Perry-Kessaris, 200I; 2003; 2008a; 20IIa; 20IIb). It certainly has not, as Yackee suggests (20I6, p. I94), been done without 'much thought given toward how to test' my hypotheses. But it has been primarily, intentionally and unapologetically qualitative. Yackee's own quantitative analysis suggested that his chosen measures of bank and multilateral aid were 'associated with' his chosen measures of Doing Business-focused reform efforts, which is in keeping with the observations made by me and other qualitative researchers. But he notes that 'we should also be careful not to exaggerate the apparent relevance of Doing Business to aid'. I agree and have paid special attention to the wording of the above paragraph to reflect that. 


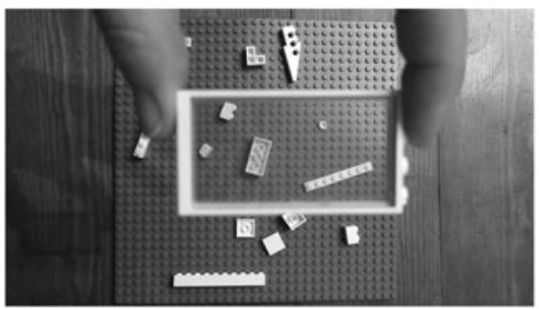

\section{Scanning}

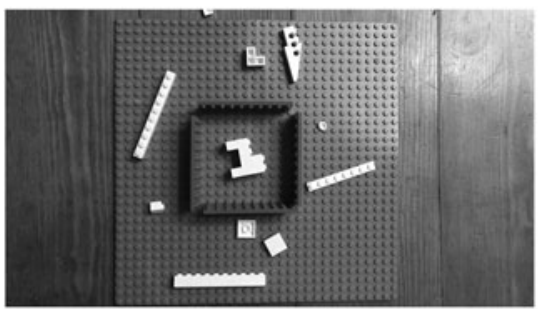

Isolation

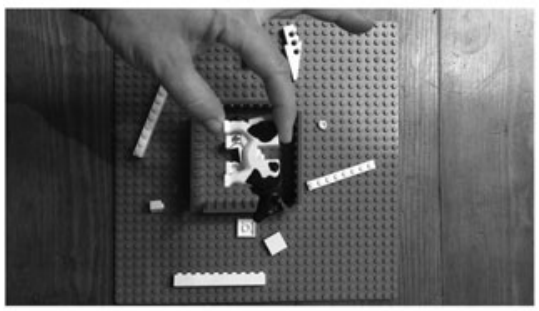

Conversion

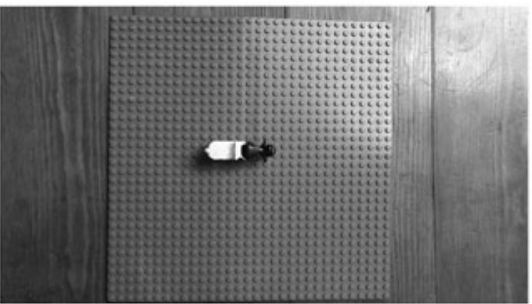

Communication

Figure 2

Constructing indicators

Source: Stills from Perry-Kessaris (2016b).

In addition to the more active roles that it plays in stimulating competition and directing conditional funding, a legal system indicator also acts as a placeholder. A placeholder is 'a technique for working with and in the meantime' - for pragmatic and other reasons (Riles, 20II, p. I73). It fulfils the human need to set our awareness of contingency and provisionality to the side. The indicator functions as a placeholder for underlying, provisional and contingent aspects of real social (including economic) life. Its form, whether presented raw as digits or visualised in a chart, is akin to a snapshot. So it is that many of Susan Sontag's (I977) foundational and unsettling observations on photography have an unexpected resonance for the understanding of indicators.

Sontag notes that photographs, and we might say indicators, are inherently value- and meaningless. The indicator/snapshot presents a world that is at once simplistically 'atomic' and therefore accessible, composed of separate images without 'interconnectedness' or 'continuity' and at the 
same time mysteriously 'opaque' (Sontag, I977, p. 23). Consequently, snapshot/indicators 'which cannot themselves explain anything, are inexhaustible invitations to deduction, speculation and fantasy' (Sontag, 1977, p. 23). They produce 'knowledge at bargain prices - a semblance of wisdom; as the act of taking pictures is a semblance of appropriation' (Sontag, 1977, p. 24). For example, despite its grand title, the 'enforcing contracts' indicator produced by the Doing Business regime refers only to judicial-based enforcement. Yet it is a treated as a placeholder for, or snapshot of, the reliability of commercial interactions generally. 3 This 'semblance of appropriation' is also visible at the country level. For example (Figure 3), Cyprus is a post-colonial, post-conflict, post-financial crisis, ethnically divided, partially occupied island located on the periphery of the EU that specialises in tourism and financial services. What of that is/not captured in this snapshot? What ought to be?

To some extent, the very generation of a snapshot/indicator itself confirms the significance, perhaps as a source of legitimacy, of the thing that is being captured by it. As Sontag put it, 'an event has come to mean, precisely, something worth photographing' (I977, p. I8). So there is a degree of self-referential circularity to the relationship between legitimacy and indicators. But ultimately 'ideology (in the broadest sense) ... determines what constitutes an event' (Sontag, I977, pp. I8-19). As Dani Rodrik argued in relation to models, what makes a snapshot/indicator 'indispensable, when used well, is that it captures the most relevant aspect of reality in a given context' (20I5, p. II, emphasis in original). The context or raison d'être of indicators/snapshots always lies beyond them. Indeed, a 2008 World Bank Independent Evaluation Group report included a section entitled 'Ideas behind the indicators'. As these ideas or rationalities change, the circle of legitimacy is broken and the indicators come under pressure. Throughout the process of coconstruction, the rationalities that underpin an indicator, and therefore its legitimacy, as well as the legitimacy that it seeks to confer, may be aligned or at odds with other rationalities.

\subsection{Legitimacy of indicators}

The Doing Business indicators can be seen as part of a wider 'campaign', the purpose of which has been to benchmark national and subnational 'investment climates', setting development standards in and through the process (Perry-Kessaris, 20IIa). That campaign has been driven by a yet broader phenomenon that Fine and Milonakis (2009) have termed 'economics imperialism'. So the Doing Business regime marketises national legal systems, treating them 'as if' they were (solely) 'commodities competing for the attentions of foreign investors'; and seeks to numericise legal systems to render them accessible to mathematisation, the analytical method of choice for mainstream economics (Perry-Kessaris, 20I Ia, p. 4I7).

Although the Doing Business regime affects all of social (including economic and legal) life, it constructs legitimacy in and through the rationalities and regimes of 'orthodox' or 'mainstream' economics. This is troubling because economics is 'the only social science that remains almost entirely impenetrable to those who have not undertaken the requisite apprenticeship in graduate school' (Rodrik, 20I5, p. 3I).

The dominance of economics is methodologically contentious because it is closed to nonspecialists, including lawyers. The Doing Business indicators are often praised and given legitimacy on the basis of their methodological transparency (Independent Evaluation Group (IEG), 2008, p. xvi). But that transparency is only as valuable as the scrutiny it facilitates. It is likely that the quantitative and econo-centric focus of the indicators exclude potential critics from investigating. Furthermore, and perhaps never more than in 20I6, there may be more fun and splash to be had from working with data sources than from questioning them.

3 These are often, erroneously, seen as being best when they are motivated purely by purpose, the task at hand. 
Doing Business in Cryprus - Wertd Bank Groud

DOING BUSINESS Measuring Business Regulations

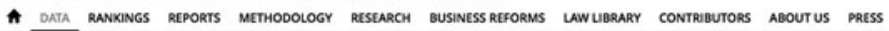

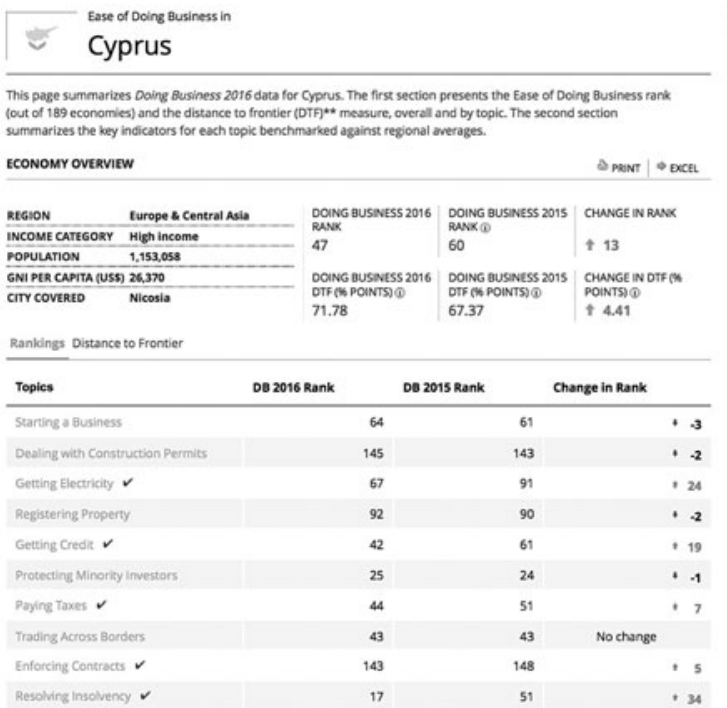

$\gamma=$ Doing Business reform making it easier to do business. $x=$ Change making it more difficult to do business Cick bere to see all reform made by cyprus.

Law

\begin{tabular}{|c|c|c|c|c|c|c|c|c|c|c|c|}
\hline $\begin{array}{l}\text { Startinga } \\
\text { Business }\end{array}$ & $\begin{array}{l}\text { Dealing with } \\
\text { Construction } \\
\text { Permits }\end{array}$ & $\begin{array}{l}\text { Getting } \\
\text { Electricity }\end{array}$ & $\begin{array}{l}\text { Registering } \\
\text { Property }\end{array}$ & $\begin{array}{l}\text { Getting } \\
\text { Credit }\end{array}$ & & $\begin{array}{l}\text { Protecting } \\
\text { Minority } \\
\text { imvestors }\end{array}$ & Paying Taxes & $\begin{array}{l}\text { Trading } \\
\text { Across } \\
\text { Borders }\end{array}$ & & $\begin{array}{l}\text { Enforcing } \\
\text { Contracts }\end{array}$ & $\begin{array}{l}\text { Resolving } \\
\text { Insolvency }\end{array}$ \\
\hline 64 & & & 92 & & 42 & 25 & 44 & & 43 & 143 & 17 \\
\hline
\end{tabular}

\begin{tabular}{|c|c|c|c|c|c|}
\hline \multicolumn{4}{|c|}{ Starting a Business $₫$} & Vew dotailis, New meethodology. & Compore al ecconomies. \\
\hline DE 2016 RANK & 64 & DE 2015 RANK $\Phi$ & 61 & CHANGE IN RANK & 4.3 \\
\hline DB 2016 DTF (S POINTS) Q & 89.23 & DB 2015 OTF (G POINTS) Q & 89.18 & CHANGE IN DTF (6 POINTS) @ & 0.05 \\
\hline
\end{tabular}

Information on new business density and number of newly created firms with limited libbility can be found at Entrepreneurship Database.

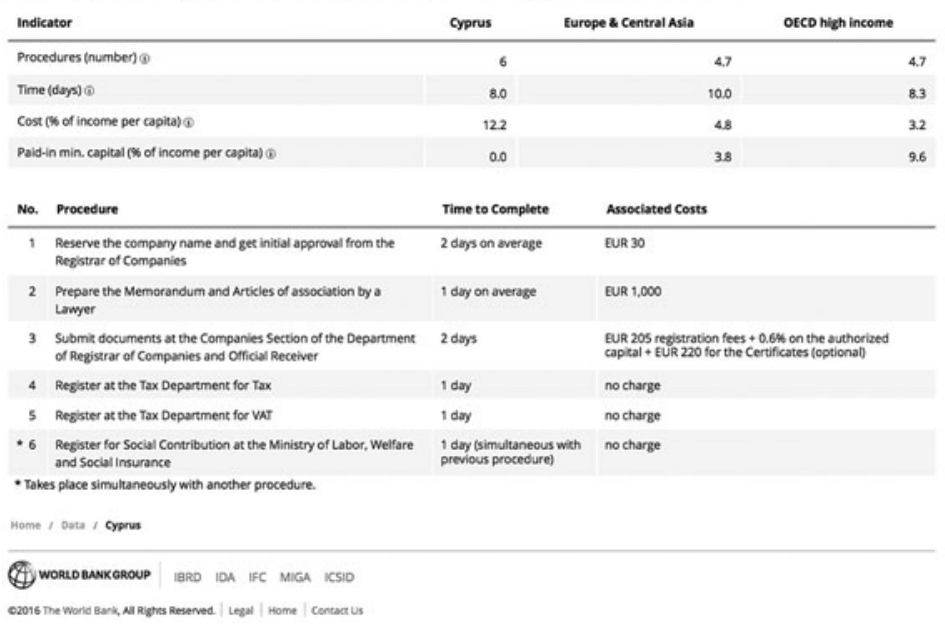

Figure 3

Snapshot of Cyprus

Source: Doing Business 20I6, 〈http://doingbusiness.org〉. 
The dominance of economics is normatively contentious because economics has in recent decades been exceptionally narrow, offering universal prescriptions centring on stabilisation, privatisation and liberalisation, especially in the context of development assistance (Rodrik, 20I5, p. I67).

It is useful to consider these two strands of contention in the context of Max Weber's typology of rationalities: pragmatic, value-based, theoretical and rule-based. ${ }^{4}$ Of less immediate relevance in the present context are pragmatic rationalities, which guide expediency and value-based rationalities, which guide taste and morality. Indicators tend instead to be a function of theoretical and formal rationalities, the former exerting a heavy influence on the latter, which is often underacknowledged especially in the pseudo-neutral context of development assistance.

Theoretical rationalities are grounded in 'a conscious mastery of reality through the construction of increasingly precise and abstract concepts' (Kalberg, I980, p. I I 52). Such concepts are often framed by academic approaches or schools of thought, such as law or economics. Rule-based rationalities are grounded in the regimes that govern economic, legal and scientific spheres (Kalberg, I980, p. I I58, cited in Perry-Kessaris, 20I5, p. 4). For example, the Doing Business indicators and other 'good governance and rule of law' indicators are widely used across jurisdiction and sector as a 'technology of governance' (Davis et al., 20II) to force a convergence on particular types of new legal standards and processes. That technology operates by a combination of economic (e.g. interstate competition) and legal (e.g. loan conditionality) regimes. But those regimes are in turn grounded in the theoretical rationalities favoured by their creators. In the case of the Doing Business indicators, those rationalities have been drawn from the market-oriented theory of neoliberal economics and have consequently emphasised that legal systems ought above all else to be efficient and predictable so as to reduce burdens on the private sector.

Because the Doing Business indicators are high-profile, long-standing and have far-reaching consequences, it is unsurprising that their legitimacy has been subject to challenge by opposing, and shifting, rationalities and regimes from outside (see e.g. Perry-Kessaris, 2008a; 2008b; Arruñada, 2009).

\section{Re-co-construction}

The legitimacy of the Doing Business indicators has also been subjected to three rounds of intensive, formal scrutiny from within the World Bank: the IEG Report (2008), the introduction of the Oversight Process for Ranking Indicators (The World Bank, 2010) and the Independent Panel report (2013). Each challenge has contributed to a slow, on-going, re-co-construction of the indicators, of their legitimacy and of the legitimacy that they seek to confer on state legal systems. Over time, the focus of these challenges has shifted between two interconnected threads. The methodological thread, grounded in formal rationalities off science, of how to measure 'ease of doing business' in a development context, has increasingly given way to a normative thread, grounded in theoretical rationalities, of why one ought to do so.

\subsection{Scientific legitimacy}

The first formal institutional challenge to the Doing Business regime came from the IEG, a body established by the World Bank Group to offer independent scrutiny of the development effectiveness of the World Bank Group. In 2008, the IEG conducted the first comprehensive evaluation of the Doing Business regime, which was then in its fourth year. It reviewed the

4 These four types were originally identified by Max Weber as practical, theoretical, substantive and formal, respectively (Kalberg, I980, p. I I47). 
underlying rationale, methodology, relevance and usage (inside and outside the bank) of Doing Business indicators.

The IEG suggested that the Doing Business indicators have been 'highly effective in drawing attention to the burdens of business regulation' (IEG, 2008, p. xv). But that achievement in communication is best read as a failure, because their legitimacy was found to be weak: they are measuring the wrong things, badly. The report noted a lack of methodological transparency; a reliance on thin datasets; an ideological bias in data selection; and a failure to monitor the impact of indicators with a view to making any necessary adjustments - what we might call 're-scanning' (IEG, 2008, p. xiii). So the Doing Business regime identifies countries as reformers' - as placeholders for what it means to be successful - 'based on changes in country rankings, without regard to the relevance and quality of the reform' or to whether those reforms have actually implemented (IEG, 2008, pp. 45, 46). Nor is there a 'clear articulation of the impact' of the reforms measured by the Doing Business regime 'on firm performance, perceptions of regulatory burden, or the overall regulatory environment in a country’ (IEG, 2008, p. 46).

These methodological critiques were responded to in the second institutional challenge that came in 2010 when the World Bank introduced of a new Oversight Process for Ranking Indicators. This 'corporate framework for oversight and quality control' promised to subject 'new products and associated indicators' to a five-stage review procedure. Furthermore, any existing 'products' that had not undergone 'extensive external and internal evaluations processes' were also open to reviewed. The 'background' explanatory narrative offered at the time for the introduction of the process pointed to problems of quantity over quality, and form over function. It focused in part on the 'reputational risk associated with the robustness of the methodology' - that is, legitimacy of what we might call the scanning, isolation and organisation elements of the indicator construction. It also questioned the legitimacy of ranking as a development tool per se:

'Over the years, the Bank has produced a variety of indicators, which provide the basis (explicitly or implicitly) for cross-country rankings, primarily of government policies, regulations and actions. Several of these indicators have been quite useful in benchmarking countries, catalyzing dialogue about reforms, and providing incentives for countries to improve performance. The process of preparation and publication of indicators has however been subject to different degrees of internal oversight, raising concerns about possible reputational risk associated with the robustness of the methodology, the consistency with the Bank's development mandate, and the communication process leading to their publication.' (The World Bank, 29 November 20Io, quoted in Perry-Kessaris, 20IIa, p. 4I6)

In 20I 2, an Independent Panel (IP) was appointed by World Bank Group President Jim Yong Kim to investigate the Doing Business regime (IP, 2013), partly in response to Chinese objections that the reports had consistently awarded it a low ranking (Harding, 2013). The formation of the IP sparked external protests, in particular from liberal-leaning economists who issued an SOS to save the indicators, complete with a dedicated e-mail address, helpdoingbusinessreport@gmail.com, at which to register support for the indicators (Khan, 2013). An open letter was received from five leading economists making the case for retaining the indicators, a core, not compelling, argument of which was that criticism of the indicators is a measure of their power (Acemoglu et al., 2013, p. I). The proceedings of the panel were the subject of such frenetic attention that the panel issued a statement asking that it be allowed to work in peace. 5

5 Dated 3 May 2013. Statement previously available at: 〈http://www.dbrpanel.org/sites/dbrpanel/files/ Statement $\% 2$ ofrom $\% 2$ othe $\% 2$ Independent $\% 20$ Panel $\% 20$ Reviewing $\% 20$ the $\% 20$ Doing $\% 20$ Business $\% 20$ Report\%20-\%20May\%203,\%202013.pdf $>$. This website has since been hijacked. 
The 2013 Panel questioned the legitimacy of the Doing Business indicators on the same two grounds as the 2008 report: legitimacy of the methodology and legitimacy of ranking in a development context. For example, the panel criticised the failure to enable the measurement of errors in data collection and analysis, and problematised the use of aggregate rankings and hypothetical case-studies. Most importantly, it found 'no scientific evidence for the report's current selection of indicators'. The snapshot was both out of focus and poorly cropped (IP, 20I3, pp. 5, 22-24).

The IP put into question the overall legitimacy of the indicators by recommending a future of 'robust oversight, governance and review' and specified that those 'tasks should not be left to the Doing Business team', since, as any lawyer or economist will tell you, 'it cannot operate as both principal and agent' (IP, 2013, p. 33). It argued that, in order 'to be consistent with the Bank's overall philosophy [the Doing Business regime] needs to empower and enable countries in their quest to develop their own reform programmes' (IP, 20I3, p. Io; see also p. 3). It also identified as significant the near total lack of connection with other sets of indicators produced by the bank such as enterprise surveys (IP, 20I3, p. 4) and with the tone of other reports such as the World Development Report on the topic of labour regulation (IP, 2013, p. 28). ${ }^{6}$

\subsection{Normative legitimacy}

The first decade of Doing Business Reports were explicitly focused on the objective of reducing the burden of regulation so that businesses and thereby, secondarily, the general population might prosper. The source of indicator legitimacy was firmly and narrowly located with the economic needs of the private sector, from which the rest of society was expected indirectly to benefit. For example, the introduction to the first report, Doing Business in 2004: Understanding Regulation, reads:

'A vibrant private sector - with firms making investments, creating jobs and improving productivity - promotes growth and expands opportunities for poor people. [This] is the first in a series of annual reports investigating the scope and manner of regulations that enhance business activity and those that constrain it.' (The World Bank, 2003, p. viii)

The 2008 report made two fairly tentative steps towards a normative critique of this emphasis on the private sector. First, it explicitly supported years of protest from civil society actors in noting that the Employing Workers Indicator wrongly focused exclusively on the costs of employment regulations to the employer, never on the benefits of those regulations to employees (IEG, 2008, p. 33). From the next year, the Employing Workers Indicator was no longer referred to in the body of Doing Business Reports or in World Bank project work, although data were still collected (IP, 20I3, p. 24).7 Second, it emphasised that the Doing Business indicators offer only a partial snapshot of the relevant factors and "cannot by themselves capture other key dimensions of a country's business climate, the benefits of regulation, or key related aspects of development effectiveness' (IEG, 2008, p. xv). The point was pressed further by the Director General of Evaluation in his summary of the proceedings of the Committee on Development Effectiveness meeting convened to discuss the evaluation and the response to it of the Management Board of

6 For a detailed statistical analysis of disparities between the Doing Business surveys (which address the de jure legal environment) and the enterprise surveys (which measure de facto legal environment), see HallwardDriemeier and Pritchett (20I5). For a more qualitative assessment of similar issues, see Perry-Kessaris (2003).

7 See also Doing Business (2009), 'Guidance Note for World Bank Group Staff on the Use of the Doing Business Employing Workers Indicator for Policy Advice', as cited in Independent Panel (IP) (20I3) 'Review of the Doing Business Report', p. 24. Available at: <http://hendrikwolff.com/web/Doing\%2obusiness\%2oreview\% 2opanel\%2oreport\%2owith\%2osignatures\%20and\%20Bibliography.pdf> (accessed ro October 2017). 
the World Bank. He specifically highlighted that the World Bank Group 'has the responsibility to emphasize' not only the 'importance of efficiency in implementing regulations' but also the 'potential value added' of those regulations (IEG, 2008, p. xxvi). Here we see the beginnings of the normative thread of critique relating to the obsessive focus on efficiency as a measure of legal system effectiveness, which, although not addressed in the 2010 intervention, would surface again in 2013 and beyond.

The 2013 Report went much deeper, challenging for the first time the core assumption of the Doing Business regime that the private sector is the priority. It noted that the Doing Business regime 'has, rightly or wrongly become associated with a broad deregulation agenda' and with the argument that 'minimal regulation and very low taxes create the most attractive environment for business', when in fact 'regulation is necessary to protect societal and environmental interests, and taxes are necessary to provide public services and build infrastructure' (IP, 20I3, p. II). Because 'indicators should provide a balanced perspective that captures both the positive and negative aspects of regulation', it was recommended that the Doing Business team 'engage with the relevant experts to ascertain the most appropriate benchmarks and refresh the economic thinking behind its indicators' (IP, 2013, p. 29).

It was after this panel report that the Doing Business team began seriously to question its own normative underpinnings. In 20I5, the first more-than-superficial note of self-criticism finally emerged from within the Doing Business team. The vehicle was the remarkably reflective Doing Business Report 2015, subtitled 'Going Beyond Efficiency'. That report states from the outset that the 'original Doing Business indicators focused mainly on measuring efficiency' but, while efficiency continues to be 'very important', there is also a need to consider 'regulatory quality' (pp. I-2). Credit for this insight is given to the 20I3 IP, as well as policy-makers and data users.

The Doing Business Report 2016: Measuring Regulatory Quality and Efficiency, continued the reflexive tone and to emphasis 'quality' as a counter-balance to the historical emphasis on efficiency. It does this ostensibly on the grounds that 'new data show that efficiency and quality go hand in hand' (The World Bank, 20I5, p. I). The latter, some might say commonsensical, point was, as in 2015, said to 'reflect consultations over the years with World Bank Group staff, country governments, the private sector, and the 20I3 Independent Panel on Doing Business' (The World Bank, 20I5, p. I).

And lo, the Doing Business Report 2016 explicitly shifts the primary source of indicator legitimacy away from the private sector and towards 'society', of which the private sector was specifically rebranded as a mere subsection:

'Societies need regulation - and businesses, as part of society, are no exception. Without the rules that underpin their establishment, operation and dissolution, modern businesses cannot exist. And where markets left to themselves would produce poor outcomes, well-designed regulation can ensure outcomes that are socially optimal and likely to leave everyone better off.' (The World Bank, 2015, p. I)

The report goes on to enumerate some of these 'socially optimal' outcomes - hitherto entirely alien to the Doing Business regime - such as fairness, balancing of power, the provision of public goods and the tempering of wealth maximising instincts (The World Bank, 2015, p. I). Most recently, Doing Business 20I 7: Equal Opportunity for All has introduced a measure for gender diversity.

\section{Shifting rationalities}

The shifts from private to public, commercial to social, that have been emphasised in the above sections are a reflection of wider trends within the World Bank and beyond (Perry-Kessaris, 20I4). The bank's World Development Report of 2015 acknowledges the role of rationalities in social, 
including economic life: 'When people think, they generally do not draw on concepts that they have invented themselves. Instead, they use concepts, categories, identities, prototypes, stereotypes, causal narratives, and worldviews drawn from their communities' (The World Bank, 20I5, p. II).

Indeed, it emphasises that 'development professionals' themselves are subject to rationalities: they are 'influenced by their social tendencies and social environments' (termed 'social thinking'); they 'use deeply ingrained mindsets' including 'disciplinary, cultural, and ideological priors' that render 'them susceptible to confirmation bias' (termed 'thinking with mental models'); and they are 'prone to error when decision-making contexts are complex' (termed 'automatic thinking'). Likewise, the World Development Report 20I7: Governance and the Law focuses all its attention on the economic, social and political complexities of rule-making and breaking. All of this sociologically relevant awareness can be traced to the rising influence of experimental and behavioural economics across the bank's approach to development - a rise that coincided with the global rethinks provoked by the 2008 financial crisis.

The IEG's initial co-constructing critique came in 2008, a most interesting of economic years (albeit since topped by 2016). During that period, even Alan Greenspan, former Chairman of the Federal Reserve, was famously confronted with his self-declared 'ideology' that 'free, competitive markets are by far the unrivalled way to organise economies', and found himself confessing

'I found a flaw ... in the model that I perceived is the critical functioning structure that defines how the world works, so to speak ... I had been going for 40 years or more with the very considerable evidence that it was working exceptionally well.' (Quoted in Patel, 20I I, p. 6)

And Greenspan was not alone on his journey from universalising model to fiddly, context-specific reality. Many other economists have faced up to the disastrous consequences of their 'omissions' in relation to the 2008 financial crisis, and their 'commissions' in the form of the universal prescriptions of the Washington Consensus to 'stabilize, privatise, liberalize' (Rodrik, 20I5, p. I67).

'Different contexts - different markets, social settings, countries, time periods and so on - require different models' (Rodrik, 20I5, p. I I). Consequently, '[w] hen models are selected judiciously, they are a source of illumination. When used dogmatically, they lead to hubris and errors in policy' (Rodrik, 20I5, p. II). All of this is now 'almost a mantra for development economists, finance experts and international agencies' who chant that 'no single set of policies is appropriate for all countries', so that 'reforms must be tailored to specific circumstances'. In this new context, legitimacy comes not from following the standard, but rather from choosing an appropriate standard for the circumstances (Rodrik, 2015, p. I67).

But the universalising ranking system of the Doing Business regime works directly against the philosophy of context specificity. It embosses both the standard (a legal system that has $\mathrm{X}$ features is 'good', and therefore legitimate) and the outcome (this country A is good/legitimate).

Once we have seen this format of legitimacy/tion, we cannot un-see it. And every effort is made to see that we do see it. Indicators - from World Development Indicators ${ }^{8}$ to Doing Business - have always occupied one of the most lavishly curated zones in the bank web presence, signifying their senior status. But the Doing Business regime has a separate domain name, doingbusiness.org, implying that it inhabits another world entirely. ${ }^{9}$ And, while another set of indicators produced by the bank, the enterprise surveys, also has a separate domain name, 'the surveys are only available on the Bank's website and do not receive as much dedicated communications support as

8 〈http://data.worldbank.org/data-catalog/world-development-indicators〉 (accessed Io October 20I7).

9 Investment Climate surveys also have a separate domain name: enterprisesurveys.org. These "rely on "soft" as opposed to statistical data - that is, interviews with managers and business owners - and provide rich data sets'. 
the Doing Business report' (IP, 2013, p. I0). Two of the institutional challenges to the Doing Business regime that will be explored in more detail below have paid close attention to the communication of the indicators. In 2008, the IEG report included a section on 'communications', which noted that 'Doing Business stands out among Bank Group products for the variety and innovativeness of the communications tools it uses' and that the reports are 'admired for their simplicity'. However, 'this sometimes undermines rigor' (IEG, 2008, pp. 4I, 42). Likewise, the IP pointed out in 2013 that the

'descriptions of topics (indicators) contained in Doing Business are, like the title of the report itself, catchy and easy to remember. However, they often make the indicators sound more comprehensive than they are, given their well-defined (and therefore limited) scope of measurement.' (IP, 20I3, p. 30)

\section{Conclusion}

Even in the most concrete, physical of spheres, the history of measurement is one of negotiation, faith and abstraction. Therefore, indicators are not neutral facilitators. The regimes and underlying rationalities in the context of which indicators are produced, distributed and consumed influence not only our perceptions of the world, but also how we perceive those perceptions.

This paper has explored the construction of the legitimacy the Doing Business indicators, and the resulting construction of the legitimacy of state legal systems through the Doing Business regime. ${ }^{\text {Io }}$ Applying a sociologically informed lens, it has shown how standards, and their legitimacy, are coconstructed by their producers and consumers across multiple, mutually constitutive levels of social life - from action and interaction to regimes and rationalities. It has emphasised that indicators offer at best a partial (in both senses of the word) snapshot of social life. If those snapshots are to contribute to knowledge, we need to look behind and beyond the Doing Business regime to the rationalities that guide it.

Behind any standard lies an on-going negotiation. In the case of the Doing Business regime, that negotiation first became visible outside the World Bank, then internal to the World Bank but external to the Doing Business team and finally within the Doing Business team itself. So a focus on the Doing Business indicators highlights tensions across the World Bank as an institution and across time. As such, it sheds light on the construction of legitimacy across 'law and development' or 'legal development' communities of practice.

Governance indicators are not new and they did not start with the World Bank. The bank was applauding (and later supporting) non-governmental organisations (NGOs) for issuing score cards ranking public services in Bengaluru and Pune as early as the mid-I990s (Perry, 1998). What has changed is that they are being issued and responded to daily, and by the city itself. Recently, the Governance Global Practice at the World Bank praised a scheme adopted by the city of Boston to use technology to collect, analyse and act upon data measuring the delivery of services such as pothole repair and waste collection, and calculating a daily 'city score' (PBS Newshour, 20I5; Lloyd, 20I6). II

Although the Doing Business indicators cannot rightly be accused of prompting the universalising tendencies of economists, they certainly support and institutionalise those tendencies. It is especially significant that legal systems are themselves setters of standards and makers of legitimacy. So whatever reforms are made to legal systems in order to pose for, or

Io In the context of the present collection, the Doing Business indicators fall within the 'good governance and rule of law' subcategory of Siems and Nelken's (2017) typology of 'global social indicators'.

I I See Twitter @wbg_gov on 29.0I.I5. 
doctor, the snapshot produced by the Doing Business regime will have a long-term social effect. What remains to be seen is whether early understandings of legitimacy under the Doing Business regime will continue to exist as 'legacy' standards - overtaken by developments but still in wide circulation.

\section{References}

ACEMoglu, Daron, Collier, Paul, johnson, Simon, kelin, Michael and wheELer, Graeme (2013) 'A Review of Doing Business', open letter, I2 May 2013. Available at: 〈http://www.doingbusiness.org/ /media/WBG/DoingBusiness/Documents/Methodology/Open-Letter-Review-of-the-Argumentson-DB.pdf> (accessed io October 2017).

ARRUÑADA, Benito (2009) 'How Doing Business Jeopardizes Institutional Reform', European Business Organization Law Review Io: 555-574.

COTTERRELL, Roger (I998) 'Why Must Legal Ideas Be Interpreted Sociologically?', Journal of Law and Society 25: I7 I-I92.

DAVIS, K., KINGSBURY, B. and MERRY, S.E. (20II) 'Indicators as a Technology of Governance’, IILJ Working Paper 2010/2. Available at: 〈http://www.iilj.org (accessed 25 October 2017).

Dorron, T. (2007) '20 ${ }^{\circ} \mathrm{C}$ : A Short History of the Standard Reference Temperature for Industrial Dimensional Measurements?', Journal of Research of the National Institute of Standards and Technology I I 2: I-23.

DRYZEK, J.S. (2005) The Politics of the Earth: Environmental Discourses. Oxford: Oxford University Press. Fine, Ben and milonakis, Dimitris (2009) From Economics Imperialism to Freakonomics. London: Routledge.

HALLWARD-DRIEMEIER, Mary and PRITCHETT, Lant (2OI5) 'How Business Is Done in the Developing World: Deals versus Rules', Journal of Economic Perspectives 29: I 2 I-I 40.

HARDING, Robin (2013) 'China Seeks to Water Down Key World Bank Report', Financial Times, 6 May. Available at: 〈http://on.ft.com/ZBz6Mn〉 (accessed io October 2017).

INDEPENDENT EVAluation Group (IEG) (2008) 'Doing Business: An Independent Evaluation - Taking the Measure of the World Bank-IFC Doing Business Indicators'. Available at: <http://go.worldbank. org/CYH45 ${ }_{4}{ }_{5} \mathrm{Go}>$ (accessed io October 2017).

INDEPENDENT PANel (IP) (2013) Review of the Doing Business Report. Available at: <http://hendrikwolff. com/web/Doing\%2obusiness\%2oreview\%2opanel\%2oreport\%2owith\%2osignatures\%2oand\% 20Bibliography.pdf> (accessed ro October 2017).

KALBERG, S. (I980) 'Max Weber's Types of Rationality: Cornerstones for the Analysis of Rationalization Processes in History', American Journal of Sociology 85(5): I I 45-I I 79.

KHAN, Robert (2013) 'Doing Business at the Word Bank', blog, I6 May 2013. Available at: <http://blogs. cfr.org/kahn/2013/05/r6/doing-business-at-the-world-bank/> (accessed io October 2017).

LLoyd, Alice (20I6) 'How Am I Doing? A New Daily Scorecard Will Soon Let Boston’s Mayor Know', blog post, I9 January. Available at: $<$ http://blogs.worldbank.org/governance/how-am-i-doing-newdaily-scorecard-will-soon-let-boston-s-mayor-know (accessed Io October 2017).

patel, R. (20I I) The Value of Nothing. London: Portobello Books.

PBS NEWSHOUR (2015) 'In Boston, Tracking Data to Score Government Progress', i 9 December. Available at: 〈https://youtu.be/cBohoeeWsmk〉 (accessed io October 2017).

PERRY, Amanda (I998) 'Law and Urban Change in an Indian City' in Edesio Fernandes and Ann Varley (eds) Illegal Cities: Law and Urban Change in Developing Countries. London: Zed Books, 89-I04. PERRY-KESSARIS, Amanda (200I) Legal Systems as a Determinant of FDI: Lessons from Sri Lanka. London: Kluwer.

PERRY-KESSARIS, Amanda (2003) 'Finding and Facing Facts about Legal Systems and FDI in South Asia', Legal Studies 23: 649-689. 
PERRY-KESSARIS, Amanda (2008a) Global Business, Local Law: The Indian Legal System as a Communal Resource in Foreign Investment Relations. Aldershot: Ashgate.

PERRY-KESSARIS, Amanda (2008b) 'Recycle, Reduce and Reflect: Information Overload and Knowledge

Deficit in the Field of Foreign Investment and the Law', Journal of Law and Society, Special Issue on Law's Reality: Empirical Research on Law S35(I): 67-75.

PERRY-KESSARIS, Amanda (20IIa) 'Prepare Your Indicators: Economics Imperialism on the Shores of

Law and Development', International Journal of Law in Context 7: 40I-42I.

PERRY-KESSARIS, Amanda (20I Ib) 'Reading the Story of Law and Embeddedness through a Community

Lens: A Polanyi-Meets-Cotterrell Economic Sociology of Law?', Northern Ireland Legal Quarterly,

Special Issue on Socializing Economic Relationships 62(4): 40I-4I3.

PERRY-KESSARIS, Amanda (20I4) 'The Case for a Visualized Economic Sociology of Legal Development',

Current Legal Problems 67: 169-198.

PERRY-KESSARIS, Amanda (20I5) 'Approaching the Econo-Socio-Legal', Annual Review of Law \& Social

Science I I: I-I 8.

PERRY-KESSARIS, Amanda (20I6a) 'Sociolegal Model Making 3: Conceptualisation', video. Available at:

$\langle$ https://vimeo.com/I85963I2I (accessed Io October 20I7).

PERRY-KESSARIS, Amanda (20I6b) 'STANDARD', video. Available at: 〈https://vimeo.com/I54506983〉

(accessed Io October 2017).

RILES, Annelise (20II) Collateral Knowledge: Legal Reasoning in Global Financial Markets. Chicago:

Chicago University Press.

RODRIK, Dani (2015) Economics Rules: Why Economics Works and When It Fails and How to Tell the

Difference. Oxford: Oxford University Press.

SIEMS, Mathias and NELKEn, David (2017) 'Global Social Indicators and the Concept of Legitimacy' (in

this issue).

SONTAG, Susan (1977) On Photography. London: Allen Lane.

WORLD BANK, THE (2003) Doing Business in 2004: Understanding Regulation. Washington, DC: The World

Bank.

WORLD BANK, THE (20I0) Oversight Process for Ranking Indicators. Washington, DC: The World Bank.

WORLD BANK, THE (2015) Doing Business Report 20I6: Measuring Regulatory Quality and Efficiency.

Washington, DC: The World Bank.

WORLD BANK, THE (2017) Word Development Report 201 7: Governance and the Law. Washington, DC: The

World Bank.

yaCKEE, Jason Webb (20I6) 'Foreign Aid, Law Reform, and the World Bank's Doing Business Project',

Law and Development Review 9: 177-I99. 